\title{
PENGARUH KUALITAS AUDIT TERHADAP KUALITAS LAPORAN KEUANGAN PEMERINTAH DAERAH
}

\author{
Moermahadi Soerja Djanegara \\ Dosen Sekolah Tinggi Ilmu Ekonomi Kesatuan \\ email: moermahadi2001@yahoo.com
}

\begin{abstract}
The purpose of this study is to determine the effect of audit quality on the quality of local government financial statements (LKPD). The quality of the audit is measured by the proxy level of completion or follow-up on the recommendation of the audit result (TLRHP), covering three factors namely the problem of weaknesses of accounting and reporting control systems, budget execution control, internal control structure, and non-compliance factor to the provisions and laws. While the quality of LKPD is measured by the proxy of audit opinion. The study sample used LKPD data from 2011-2015 provinces, cities and districts in Java and Sumatera region covering 279 LKPD (51\%) of LKPD population throughout Indonesia. The result of analysis with regression method (least square method) shows that follow-up improvement over weakness of accounting and reporting control, budget execution control, internal control structure, and compliance to regulation and legislation have positive effect to LKPD quality. The greatest influence is shown by improvements over the weaknesses of accounting and reporting control systems. The implications of the research results are to improve the quality of LKPD, monitoring the follow-up improvement on the recommendations of LKPD audit results by BPK auditors should be intensified, with priority monitoring on TLRHP issues of weaknesses of accounting and reporting control systems.
\end{abstract}

Keywords: Public Sector, Audit Quality, Internal Control System, Regulatory Compliance, Follow-up Inspection Result, Quality of Financial Statement

\begin{abstract}
Abstrak: Tujuan penelitian adalah untuk mengetahui pengaruh kualitas audit terhadap kualitas laporan keuangan pemerintah daerah (LKPD). Kualitas audit diukur dengan proksi tingkat penyelesaian atau tindak lanjut atas rekomendasi hasil audit (TLRHP), meliputi tiga faktor yaitu permasalahan kelemahan sistem pengendalian akuntansi dan pelaporan, pengendalian pelaksanaan anggaran, struktur pengendalian intern, dan faktor ketidakpatuhan terhadap ketentuan dan peraturan perundang-undangan. Sedangkan kualitas LKPD diukur dengan proksi opini audit. Sampel penelitian menggunakan data LKPD tahun 2011-2015 provinsi, kota, dan kabupaten di wilayah Jawa dan Sumatera meliputi 279 LKPD (51\%) dari populasi LKPD seluruh Indonesia. Hasil analisis dengan metode regresi (least square method) menunjukkan bahwa tindak lanjut perbaikan atas kelemahan pengendalian akuntansi dan pelaporan, pengendalian pelaksanaan anggaran, struktur pengendalian intern, dan kepatuhan terhadap peraturan dan perundang-undangan berpengaruh positif terhadap kualitas LKPD. Pengaruh terbesar ditunjukkan oleh perbaikan atas kelemahan sistem pengendalian akuntansi dan pelaporan. Implikasi dari hasil penelitian yaitu untuk meningkatkan kualitas LKPD, pemantauan tindak lanjut perbaikan atas rekomendasi hasil audit LKPD oleh auditor BPK harus diintensifkan, dengan prioritas pemantauan atas TLRHP permasalahan kelemahan sistem pengendalian akuntansi dan pelaporan.
\end{abstract}


Kata kunci: Sektor Publik, Kualitas Audit, Sistem Pengendalian Intern, Kepatuhan terhadap Peraturan, Tindak Lanjut Hasil Pemeriksaan, Kualitas Laporan Keuangan.

\section{PENDAHULUAN}

Kualitas audit dan kualitas pelaporan keuangan menjadi isu yang banyak mendapat perhatian sejak terjadinya berbagai skandal dan masalah ekonomi pada beberapa dekade yang lalu (Knechel, 2009:2). Oleh karenanya, perbaikan kualitas audit dan pelaporan keuangan di berbagai sektor ekonomi menjadi krusial (IAASB, 2013).

Tujuan laporan keuangan entitas sektor publik adalah menyediakan informasi tentang entitas pelaporan yang berguna untuk tujuan akuntabilitas dan pengambilan keputusan (IFAC, 2014:7). Laporan keuangan pada hakekatnya merupakan mekanisme akuntabilitas dan pemenuhan kewajiban pertanggungjawaban atas pengelolaan keuangan yang bersumber dari pembayar pajak, donatur, kreditur, dan sumber lainnya, dalam rangka meningkatkan pelayanan dan kesejahteraan bagi warga negara dan pihak lainnya (ANAO, 2015; IFAC. 2014:13; Wynne, 2003:5). Hasil penelitian terdahulu menunjukkan bahwa laporan keuangan yang berkualitas tinggi dapat memitigasi problem asimetri informasi (Healy \& Palepu, 2001; Verdi, 20069), moral hazard (Biddle et al., 2009; McDermott, 2011) sehingga meningkatkan efisiensi dan efektivitas alokasi serta utilisasi sumberdaya ekonomi (Bushman \& Smith, 2001; World Bank, 2011; Feng Chen, et al., 2010).

Tujuan audit laporan keuangan sektor publik adalah untuk auditor memberikan opini berdasarkan bukti-bukti audit yang cukup dan tepat, apakah laporan keuangan yang disajikan entitas bebas dari salah saji material (IAASB, 2014:4). Pada umumnya laporan auditor menjadi indikator keandalan laporan keuangan bagi sebagian besar pemakai laporan keuangan, karena informasi hasil audit diasumsikan lebih lengkap, akurat, tidak bias (Arens et.al, 2012), dan laporan keuangan yang mendapat opini audit wajar tanpa pengecualian (unmodified auditor's report) semakin meningkatkan kepercayaan parlemen, dewan legislatif dan pemangku kepentingan lainnya terhadap entitas (ANAO, 2015). Namun demikian, sampai saat ini belum ada definisi kualitas audit atau kesimpulan empirik tentang kualitas audit yang disepakati secara universal (IAASB, 2014:2; FRC, 2006; Bing et al., 2014:2).

Menurut IFAC (2013:10) " ... a quality audit is likely to be achieved when the auditor's opinion on the financial statements can be relied upon". Dalam laporan peerreview terhadap BPK tahun 2013, SAO Poland (2014) menyimpulkan bahwa hasil audit BPK "...highly appreciated by the national Parliament and regional legislative assemblies. Selain itu BPK dinilai sebagai organisasi audit yang kuat, independen, dan professional. "As the Reviewer found through interviews with the BPK's stakeholders, it is regarded as a strong, independent and professional organisation" (SAO Poland, 2014). Keunggulan BPK yaitu memiliki pedoman audit yang komprehensif, staf berpendidikan, open-minded, serta memiliki kultur organisasi yang baik, patuh dan disiplin terhadap prosedur (SAO Poland, 2014).

Defond, \& Zhang (2014:275) berpendapat bahwa semakin tinggi kualitas audit semakin tinggi kualitas laporan keuangan, karena kualitas audit akan memperbaiki kredibilitas laporan keuangan, karena sejalan dengan pendapat Deloitte (2015:54-55) bahwa "Audit findings help improve the financial statements to enable full compliance with IPSAS". Dengan kata lain kualitas audit adalah bagian dari komponen kualitas pelaporan keuangan (Defond, \& Zhang, 2014:276). 
Berkaitan dengan hasil audit BPK, berdasarkan data Ikhtisar Hasil Pemeriksaan Semester (IHPS) II Tahun 2016, dalam lima tahun terakhir (2011-2015), jumlah LKPD yang mendapat opini WTP meningkat dari 13\% pada tahun 2011 menjadi 58\% pada pada tahun 2015. Gambar 1 menunjukkan perkembangan opini audit BPK terhadap LKPD nasional sejak tahun 2011-2015:

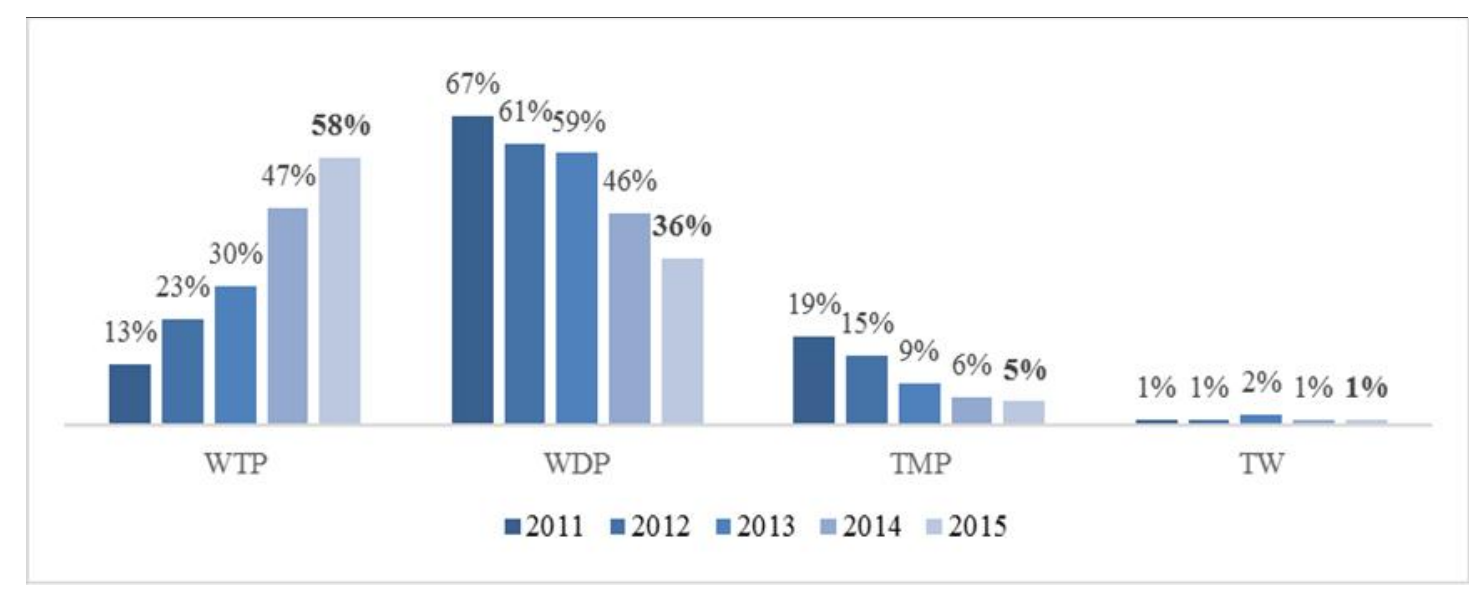

Gambar 1. Perkembangan Opini Audit Tahun 2011-2015

Sumber: Ikhtisar Hasil Pemeriksaan Semester (IHPS) II Tahun 2016 (diolah).

Berdasarkan data di atas, meskipun menunjukkan peningkatan kualitas LKPD masih terdapat $42 \%$ atau 221 LKPD dari keseluruhan 542 LKPD yang belum mendapatkan opini WTP. Perbaikan kualitas LKPD ditentukan efektivitas sistem pengendalian intern dan kepatuhan terhadap peraturan perundang-undangan sehingga LKPD disajikan sesuai Standar Akuntansi Pemerintah (SAP) (IHPS I, 2016:81).

Tanggung jawab kualitas audit atas laporan keuangan terletak pada auditor. Akan tetapi, kualitas audit hanya akan terealisasi dengan baik apabila didukung sistem pelaporan keuangan dan karakteristik lingkungan di dalam entitas, karena kedua faktor tersebut seringkali menghambat tercapainya kualitas laporan keuangan (IFAC, 2014:4; Defond, \& Zhang, 2014:276).

Menurut IFAC (2013:62) "Actions taken by the entity in response to recommendations are often recorded and seen as an expression of the value from the audits" . INTOSAI dalam ISSAI 3000:50 menetapkan " ... the objectives of follow-up audit are basically to help augment the effectiveness of audit report". Dalam Standar Pemeriksaan Keuangan Negara (SPKN, 2017:10;61) ditetapkan bahwa pemantauan tindak lanjut hasil pemeriksaan merupakan salah satu unsur pemeriksaan keuangan negara untuk meningkatkan efektivitas pelaporan hasil pemeriksaan dan membantu lembaga perwakilan dan pemerintah dalam memperbaiki tata kelola (SPKN, 2017:61). Namun demikian, sampai dengan tahun 2016, tingkat tindak lanjut atas rekomendasi yang menjadi salah satu indikator kualitas audit BPK secara keseluruhan baru mencapai 50-60\% (Laporan Akuntabilitias Kinerja BPK, 2016:14).

Menurut Ince (2016:120) dalam artikel "Follow-Up Mechanism: A Mising-Link in Audit Cycle", pemantauan tindak lanjut merupakan pelengkap filosofi audit yang paling kritikal dalam rangka meningkatkan kesadaran akuntabilitas. Oleh karenanya, praktik dan kinerja terbaik bagi audit publik sektor hanya melalui mekanisme tindak lanjut yang efektif. Hasil penelitian terdahulu Setyaningrum et al., (2013:89), menggunakan data 
LKPD tahun 2010-2012, menemukan bahwa kualitas audit berpengaruh positif terhadap tindak lanjut atas rekomendasi audit. Temuan ini mengindikasikan bahwa "... high quality auditor is able to produce appropriate recommendations that can be easily followed up by the auditee" dan dampaknya yaitu "The more recommendations are acted upon, the better the quality of local government financial statements". Aikins (2012:198) menggunakan data hasil audit internal di Amerika menemukan bahwa tindak lanjut perbaikan merupakan fungsi dari profesionalisme, kecermatan (due diligence), relasi dengan klien, dokumentasi, dan verifikasi atas implementasi rekomendasi. Menurut Gichana (2015:9) kontribusi tindak lanjut dapat disebabkan efektivitas rekomendasi atau sebaliknya karena rekomendasi tidak spesifik. Septiana (2011:178-179) menemukan bahwa laporan audit BPK banyak yang tidak ditindaklanjuti, sehingga seberapa pun banyaknya temuan audit, tanpa tindaklanjut perbaikan secara signifikan akan sulit memperbaiki kinerja pemerintah. Permasalahan lain yaitu BPK tidak memiliki kewenangan menghukum auditi yang tidak melakukan perbaikan. Namun menurut Gichana (2015:9) kontribusi tindak lanjut dapat disebabkan efektivitas rekomendasi atau sebaliknya karena rekomendasi tidak spesifik.

Tindak lanjut perbaikan atas kelemahan sistem pengendalian intern dapat mencegah, mendeteksi, mengoreksi kesalahan (Garrett, et al., 2012:17) sehingga laporan keuangan disajikan secara wajar (Ratcliffe \& Landes, 2009) dan sekaligus memitigasi kecurangan pelaporan keuangan (Amernic, 2010:11). Pada umumnya defisiensi signifikan (material weakness) atas pengendalian intern disebabkan kegagalan manajemen melakukan tindakan perbaikan secara tepat (IAPI, 2013: SA 265.7-8), sedangkan kecurangan pelaporan keuangan disebabkan manajemen mengabaikan (override) sistem pengendalian intern (IAPI, 2013: SA550.19-20; Hermanson et al., 2012: A48; COSO, 2011:14; Arens, et al., 2014:309). Hasil penelitian terdahulu Thanh \& Cheung (2010) menggunakan sampel 152 perusahaan menemukan bahwa perusahaan yang laporan pengendalian internalnya baik, maka kualitas akuntansi baik. Doyle et al. (2007), menggunakan data 705 perusahaan, membuktikan bahwa pengendalian internal yang lemah berhubungan penurunan kualitas pelaporan keuangan. Ashbaugh-Skaife et al. 2008 dalam Hunton, et al. (2010) dan $\mathrm{He}$ (2009) menemukan hubungan yang positif antara perbaikan pengendalian intern dengan kualitas laporan keuangan.

Dalam kaitannya dengan kepatuhan terhadap peraturan perundang-undangan, Zhang et al. (2016) menemukan bahwa perusahaan yang tidak taat terhadap hukum (securities laws) permasalahan pelaporan keuangannya secara signifikan lebih tinggi disertai tingginya tingkat penggantian pimpinan perusahaan. Nagy (2010) menemukan hubungan negatif dan signifikan antara kepatuhan dengan kesalahan penyajian laporan keuangan. Kedia et al., (2016:1) menggunakan data 22,885 perusahaan-tahun selama 1994-2011 menemukan bahwa dalam perusahaan yang memiliki budaya tidak patuh cenderung salah dalam menyajkian laporan keuangan.

Berdasarkan uraian sebagaimana dikemukakan di atas, kualitas audit berkaitan dengan tindak lanjut temuan hasil audit atas kelemahan sistem pengendalian intern dan kepatuhan terhadap peraturan perundang-ungangan dapat meningkatkan kualitas LKPD.

\section{KAJIAN TEORI}

Agency Theory \& Entity Theory. Salah satu problem pemisahan kepemilikan dengan pengeloalan sumberdaya ekonomi adalah problem hubungan keagenan (principal-agency problem) yang disebabkan asimetri informasi, karena prinsipal tidak memiliki akses 
terhadap semua informasi dan tidak dapat memastikan apakah aksi manajemen sepenuhnya untuk kepentingan terbaik entitas (Jensen \& Meckling, 1976, Adams, 1994; Miettinen, 2008). "If both parties to the relationship are utility maximizers, there is good reason to believe that the agent will not always act in the best interests of the principal", sehingga ada cukup alasan untuk mengatakan bahwa agen tidak selalu memaksimalkan kepentingan prinsipal (Jensen \& Meckling, 1976 dalam Brennan, 2008).

Dari perspektif entitas (entity theory), laporan keuangan entitas dianggap sebagai pengganti kepemilikan, karena pemilik modal memiliki sebagian klaim sehingga berhak untuk mendapatkan sumberdaya yang mereka miliki dalam laporan keuangan entitas (IASB, 2008; Chau, 2011; Franklin Strier, 2005; Ararat dan Ugur, 2003). Menurut Monks \& Minnow (1990) dalam setiap kasus, penyebab utamanya adalah kegagalan struktural mekanisme pengawasan internal, sedangkan secara umum Messier (2016:6) berpendapat "The demand for auditing can be understood as the need for accountability when business owners hire others to manage their businesses.

Dalam suatu mekanisme tata kelola yang baik, audit eksternal yang independen terhadap entitas merupakan fungsi "check and balance" untuk memitigasi asimetri informasi (Jensen \& Meckling, 1976; Daniri, 2006; Miettinen, 2008) dan meningkatkan transparansi laporan keuangan. "External audits play a strong corporate governance role and are instrumental in supporting transparent financial reporting" (Ashbaugh \& Warfield, 2003 dalam Palmer, 2008).

Kualitas Audit. Suatu pemeriksaan memiliki nilai karena kemampuan menyediakan jaminan (assurance) secara independen atas kredibilitas informasi akuntansi, yang memperbaiki pengalokasian sumberdaya dan peningkatan efisiensi (Zhang et al., 2016:275). Secara umum, audit sektor publik meliputi satu atau tiga jenis audit yaitu audit laporan keuangan, audit kepatuhan, dan audit kinerja. Akan tetapi semua audit sektor publik berawal dari tujuan memberikan kontribusi terhadap tata kelola yang baik (good governance) dengan (a) menyediakan informasi independen, obyektif, dapat diandalkan, dan kesimpulan atau opini ditetapkan berdasarkan bukti yang cukup dan tepat berkaitan dengan entitas publik; (b) meningkatkan akuntabilitas dan transparansi, mendorong perbaikan, dan kepercayaan berkelanjutan atas ketepatan pemakaian dana dan asset serta kinerja administrasi publik; (c) mendorong efektivitas unit yang menjalankan fungsi pemantauan dan koreksi atas pemerintahan, dan pihak-pihak yang bertanggung jawab atas aktivitas yang dananya bersumber dari publik; (d) menciptakan insentif perubahan dengan pengetahuan, analisis komprehensif, dan rekomendasi yang kuat untuk perbaikan (INTOSAI dalam ISSAI 100:7).

Tujuan audit laporan keuangan sektor publik adalah pemberian assurance apakah laporan keuangan entitas menyajikan secara wajar dari seluruh aspek material sesuai dengan standar akuntansi yang berlaku, berdasarkan bukti audit yang cukup dan tepat, sehingga auditor memberikan opini atas laporan keuangan atau tidak memberikan pendapat (disclaimer), tergantung kesesuaian dengan standar akuntansi (Kearney et al., 2013:11; IAASB, 2014:4). Untuk memperoleh keyakinan yang memadai atas kewajaran laporan keuangan tersebut, dilakukan pemeriksaan terhadap sistem pengendalian intern dan kepatuhan terhadap ketentuan peraturan perundang-undangan (SPKN, 2017:68) dan pengujian kepatuhan terhadap peraturan dan perundang-undangan dalam rangka untuk memberikan keyakinan memadai melalui pendeteksian kemungkinan penyimpangan material bagi laporan keuangan, mendeteksi kesalahan/kekeliruan dalam laporan keuangan 
sebagai akibat langsung perbuatan melanggar/melawan hukum yang material, serta untuk menumbuhkan kewaspadaan kemungkinan telah terjadinya unsur perbuatan melawan hukum, baik secara langsung maupun tidak langsung. Dalam Petunjuk Pelaksaaan Pemeriksaan Keuangan BPK RI Nomor 4/K/1-XIII.2/7/2014 ditetapkan bahwa laporan hasil pengujian sistem pengendalian intern diterbitkan hanya jika ditemukan kelemahankelemahan pengendalian intern selama pelaksanaan pemeriksaan.

Pada level penugasan, audit laporan keuangan umumnya diperluas, yaitu tidak hanya menilai kewajaran penyajian laporan keuangan sesuai standar akuntansi yang berlaku, akan tetapi juga melakukan penilaian atas sistem pengendalian intern dan kepatuhan terhadap peraturan dan perundang-undangan (Kearney et al., 2013:6; IAASB, 2013:62). Di BPK, sesuai Petunjuk Pelaksanaan Pemeriksaan Keuangan BPK RI Nomor 4/K/1XIII.2/7/2014, tujuan pemeriksaan keuangan adalah untuk memberikan keyakinan yang memadai (reasonable assurance) apakah laporan keuangan telah disajikan secara wajar dalam semua hal yang material, sesuai dengan prinsip akuntansi yang berlaku umum di Indonesia atau basis akuntansi komprehensif selain prinsip akuntansi yang berlaku umum di Indonesia dengan memperhatikan (1) kesesuaian laporan keuangan dengan standar akuntansi; (2) kecukupan pengungkapan; (3) kepatuhan terhadap peraturan perundangundangan; dan (4) efektivitas sistem pengendalian intern. Sedangkan jenis laporan hasil pemeriksaan keuangan terdiri atas laporan hasil pemeriksaan (LHP) laporan keuangan, LHP Kepatuhan terhadap peraturan perundang-undangan, dan LHP atas Sistem Pengendalian Internal.

Berkaitan dengan definisi kualitas audit, sampai dengan saat ini belum ada definisi atau kesimpulan empirik tentang kualitas audit yang telah disepakati secara universal. Menurut IAASB (2014:2) "Audit quality is a complex subject... there is no definition or analysis of it that has achieved universal recognition". The Financial Reporting Council (FRC, 2006) berpendapat meskipun studi empirik menyarankan berbagai definisi tentang kualitas audit, "no perfect definition can be used as a guideline to evaluate real audit quality". Demikian Bing et al., (2014:2) berdasarkan hasil analisis penelitian terdahulu menyimpulkan bahwa "There is no consensus as to which proxies for audit quality are best suited for any particular research objectives". Namun, terlepas dari perbedaan pendapat tentang kualitas audit, pemakai laporan keuangan pada umumnya menilai bahwa laporan auditor independen sebagai indikator keandalan laporan keuangan, karena diasumsikan laporan keuangan yang telah diaudit menyajikan informasi lebih lengkap, akurat, dan tidak bias (Arens et.al., 2012). Laporan keuangan yang mendapat opini audit wajar tanpa pengecualian (unmodified auditor's report), akan meningkatkan kepercayaan parlemen, dewan legislatif dan pemangku kepentingan lainnya terhadap entitas (ANAO, 2015).

Menurut IAASB (2011), secara konseptual perspektif kualitas audit dapat dilihat dari tiga aspek fundamental yaitu faktor input, output, dan konteks. Faktor input antara lain atribut personal auditor, seperti ketrampilan (skill) dan pengalaman auditor, nilai etis, pola pikir (mindset), dan proses audit termasuk metodologi audit, efektivitas alat bantu audit, dan ketersediaan pendukung teknis lainnya. Faktor output audit berpengaruh penting terhadap kualitas audit karena seringkali dipertimbangkan stakeholder dalam penilaian kualitas audit. Laporan auditor berpengaruh positif terhadap kualitas audit apabila hasil (outcome) audit yang disampaikan jelas disertai komunikasi permasalahan yang ditemukan dengan pihak yang bertanggungjawab terhadap tata kelola (those charged with 
governance), seperti aspek kualitatif praktik pelaporan keuangan entitas dan kelemahan pengendalian intern dapat berpengaruh positif terhadap kualitas audit. (IAASB, 2011).

Namun Defond, \& Zhang (2014:276) berdasarkan hasil analisis penelitian terdahulu berpendapat bahwa kualitas audit hanya akan tercapai apabila didukung sistem pelaporan keuangan dan karakteristik bawaan (innate characteristic) pada auditi, karena kedua hal ini seringkali menghambat tercapainya kualitas laporan keuangan. Menurut DeAngelo (1981:186), kualitas audit adalah probabilitas auditor menemukan penyimpangan dan kemampuan melaporkan penyimpangan akuntansi. Berdasarkan hasil analisis disimpulkan bahwa output audit dapat dianggap sebagai karakteristik verifikasi auditor independen, sedangkan opini yang diberikan berkaitan dengan dimensi kualitas keuangan manajemen.

Menurut Ince (2016:120), dalam siklus audit yang seringkali terlupakan (misinglink) yaitu mekanisme tindak lanjut untuk meningkatkan kesadaran akuntabilitas manajemen entitas publik. Oleh karenanya pemantauan tindak lanjut merupakan bagian dari filosofi audit paling kritikal. Dengan demikian, praktik dan kinerja terbaik audit publik sektor hanya melalui mekanisme tindak lanjut yang efektif. Pendapat ini sejalan dengan IFAC (2013:62) yang menyatakan "Actions taken by the entity in response to recommendations are often recorded and seen as an expression of the value from the audits". Pendapat tersebut juga sesuai dengan standar internasional audit ISSAI 3000:50 INTOSAI bahwa "... the objectives of follow-up audit are basically to help augment the effectiveness of audit report". Demikian juga dalam SPKN (2017:10;61) dinyatakan bahwa pemantauan tindak lanjut hasil pemeriksaan meningkatkan efektivitas pelaporan hasil pemeriksaan (SPKN, 2017:61).

Hasil penelitian terdahulu Setyaningrum et al., (2013:89), berdasarkan data LKPD tahun 2010-2012, menemukan bahwa kualitas audit berpengaruh positif terhadap tindak lanjut atas rekomendasi audit, sehingga menyimpulkan bahwa "... high quality auditor is able to produce appropriate recommendations that can be easily followed up by the auditee" dan dampaknya yaitu "The more recommendations are acted upon, the better the quality of local government financial statements". Penelitian lainnya, menggunakan data hasil audit internal local government di Amerika, Aikins (2012:198) menemukan bahwa tindak lanjut perbaikan merupakan fungsi dari profesionalisme, kecermatan (due diligence), relasi dengan klien, dokumentasi, dan verifikasi atas implementasi rekomendasi. Menurut Gichana (2015:9) penilaian atas kontribusi tindak lanjut perlu hatihati, karena dapat disebabkan efektivitas rekomendasi atau sebaliknya karena rekomendasi tidak spesifik. Berdasarkan hasil interview, peneliti terdahulu Septiana (2011:178-179) menemukan auditor menyatakan bahwa "No matter how many audit findings and how actively BPK audits state finances, without significant follow-up from audited entities, it will be difficult to provide better government performance. Pernyataan ini menegaskan bahwa tindak lanjut hasil temuan audit sangat penting (Septiana, 2011:180). Secara keseluruhan rekomendasi atas temuan dan permasalahan berdasarkan hasil pemeriksaan BPK sampai dengan tahun 2016 berjumlah 243.648 rekomendasi dengan status 133.441 (54\%) rekomendasi telah selesai ditindaklanjuti, 70.817 (29\%) masih dalam proses, $38.390(15 \%)$ belum ditindaklanjuti, dan $460(0,18 \%)$ tidak dapat ditindaklanjuti sesuai prosedur dan ketentuan. Untuk itu BPK terus berupaya untuk merumuskan rekomendasi yang dapat ditindaklanjuti oleh entitas yang diperiksa (auditee) dan mendorong peningkatan pada kegiatan operasional atau kinerja auditee. 


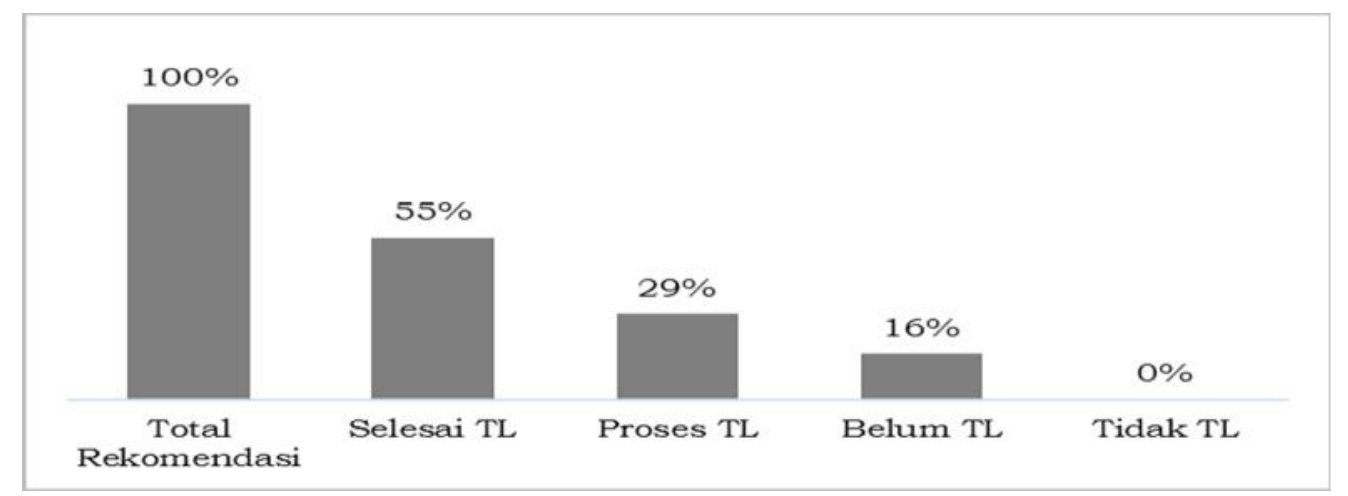

Gambar 2. Status Tindak Lanjut atas Rekomendasi BPK Tahun 2016

Sumber: Laporan Akuntabilitas Kinerja BPK Tahun 2016 (diolah)

Menurut Gichana (2015:9) kontribusi tindak lanjut dapat disebabkan efektivitas rekomendasi atau sebaliknya karena rekomendasi tidak spesifik. Akan tetapi Septiana, (2011:180) menyimpulkan permasalahan lain dari masih rendahnya tindak lajut atas hasil audit yaitu karena BPK tidak memiliki kewenangan menghukum auditi yang tidak melakukan perbaikan.

Tindak lanjut atas Kelemahan Pengendalian intern. Sistem pengendalian intern dirancang untuk menyediakan jaminan yang layak bagi manajemen memperoleh laporan keuangan yang andal (reliabile), tepat waktu (timeliness), transparan, dan persyaratan lain sesuai ketentuan (COSO, 2013:3). Sistem pengendalian harus dapat mencegah, mendeteksi, dan mengoreksi kesalahan penyajian laporan keuangan tepat waktu. Apabila tidak dapat mencegah, mendeteksi, dan mengoreksi, maka auditor menilai adanya defisiensi. Apabila terdapat kelemahan material (material weakness) dalam pelaporan keuangan atau ketidakpatuhan terhadap peraturan, maka manajemen tidak boleh menyimpulkan bahwa pengendalian intern efektif (COSO, 2011:14).

Dari perspektif auditor eksternal, risiko kesalahan pelaporan keuangan dapat terjadi pada dua tingkat yaitu risiko kesalahan laporan keuangan secara keseluruhan, kesalahan transaksi, kesalahan saldo akun, dan pengungkapan (IAPI, 2013: SA200.24).. Defisiensi pengendalian internal yang signifikan (material weakness) diantaranya disebabkan kegagalan manajemen melakukan tindakan perbaikan secara tepat atau manajemen tidak melakukan pengawasan pelaporan keuangan (IAPI, 2013: SA265.7-8). Defisiensi signifikan (material weakness) pengendalian internal dapat menimbulkan pertanyaan tentang integritas atau kompetensi manajemen. Misalnya, auditor menemukan bukti ketidakpatuhan manajemen terhadap peraturan perundang-undangan atau ketidakmampuan manajemen melakukan pengawasan proses penyusunan laporan keuangan (IAPI, 2013: SA265.12). Pada umumnya, kecurangan pelaporan keuangan disebabkan manajemen mengabaikan (override) sistem pengendalian intern (IAPI, 2013: SA550.19-20; Hermanson, et al., 2012:A48; COSO,2011:14; Arens, et al., 2014:309).

Dalam Petunjuk Pelaksaaan Pemeriksaan Keuangan BPK RI Nomor 4/K/1XIII.2/7/2014, sistem pengendalian internal didefinisikan sebagai suatu proses integral yang dirancang dan diimplementasikan oleh pimpinan dan seluruh pegawai untuk memberikan keyakinan yang memadai terhadap pencapaian tujuan entitas terkait dengan efektivitas dan efisiensi operasi, keandalan dari laporan keuangan, ketaatan terhadap 
peraturan perundang-undangan, dan pengamanan aset. Menurut Benedek et al., (2014:298), tujuan sistem pengendalian intern adalah untuk memastikan bahwa semua aktivitas dilaksanakan secara ekonomis, efisien, dan efektif dan sesuai dengan peraturan yang berlaku serta secara alamiah memenuhi persyaratan akuntansi yang telah ditetapkan (Benedek et al., 2014:297). Menurut beberapa pakar, sistem pengendalian intern dapat mencegah, mendeteksi, mengoreksi kesalahan (Garrett, et al. 2012:17) sehingga laporan keuangan disajikan secara wajar (Ratcliffe \& Landes, 2009) dan sekaligus memitigasi kecurangan pelaporan keuangan (Amernic, 2010:11). Secara umum dapat dikatakan bahwa defisiensi signifikan (material weakness) atas pengendalian intern disebabkan kegagalan manajemen melakukan tindakan perbaikan secara tepat (IAPI, 2013: SA 265.78), tetapi pengabaian (override) terhadap sistem pengendalian intern oleh manajemen menjadi pemicu indikasi kecurangan pelaporan keuangan (IAPI, 2013: SA550.19-20; Hermanson et al., 2012: A48; COSO, 2011:14; Arens, et al., 2014:309).

Menurut hasil penelitian Thanh \& Cheung (2010) dengan sampel data 152 perusahaan menemukan bahwa perusahaan yang laporan pengendalian internnya baik, kualitas akuntansinya baik. Menurut hasil penelitian Doyle et al. (2007), menggunakan data 705 perusahaan, membuktikan bahwa pengendalian intern yang lemah berhubungan dengan penurunan kualitas laporan keuangan. Ashbaugh-Skaife et al., 2008 dalam Hunton, et al. (2010) dan He (2009) menemukan hubungan yang positif antara perbaikan pengendalian intern dengan kualitas laporan keuangan.

Berdasarkan uraian definisi dan hasil penelitian terdahulu, dapat dikatakan bahwa tindak lanjut perbaikan atas kelemahan pengendalian intern merupakan indikator kualitas audit (misalnya Ince, 2016:120; IFAC, 2013:62) yang pada akhirnya berdampak positif pada kualitas laporan keuangan (misalnya, Deloitte, 2015:54-55; Defond, \& Zhang, 2014:275)

Tindak lanjut atas ketidakpatuhan. Audit kepatuhan yaitu menguji prosedur, mendeteksi, dan mencegah aktivitas transaksi yang menyimpang dari ketentuan pengelolaan keuangan negara. Di beberapa negara, mandat ini ditujukan sebagai dukungan program anti korupsi (Nicoll, 2005 dalam Septiana, 2011:2-3).

Penelitian empirik terhadap sistem tindak lanjut rekomendasi audit masih sangat langka (Brooks \& Pariser, 1995). Hasil penelitian terdahulu Zhang et al. (2016) menemukan bahwa perusahaan yang tidak taat terhadap hukum (securities laws) permasalahan pelaporan keuangannya secara signifikan lebih tinggi disertai tingginya tingkat penggantian pimpinan perusahaan. Nagy (2010) menemukan hubungan negatif dan signifikan antara kepatuhan dengan kesalahan penyajian laporan keuangan. Kedia et al., (2016:1) menggunakan data 22,885 perusahaan-tahun selama 1994-2011 menemukan bahwa dalam perusahaan yang memiliki kultur tidak patuh cenderung salah penyajian laporan keuangan.

Berdasarkan beberapa definisi dan uraian sebagaimana telah dikemukakan, dapat dikatakan bahwa tindak lanjut perbaikan atas ketidakpatuhan peraturan dan perundangundangan merupakan indikator kualitas audit (misalnya Ince, 2016:120; IFAC, 2013:62) yang pada akhir berdampak positif pada kualitas laporan keuangan (misalnya, Deloitte, 2015:54-55; Defond, \& Zhang, 2014:275; ISSAI 100).

Kualitas Laporan Keuangan. Pemerintah dan entitas sektor publik lainnya meningkatkan sumber daya bersumber dari pembayar pajak, sumbangan, kreditur, dan sumber lain untuk menyelenggarakan dan menyediakan jasa pelayanan serta 
meningkatkan atau mempertahankan kesejahteraan warga negaranya. Pelayanan jasa publik antara lain program kesejahteraan, pendidikan, keamanan dan pertahanan nasional. Dalam banyak hal, jasa yang disediakan pemerintah tidak berbentuk pertukaran atau perdagangan dan seringkali tidak kompetitif. Terhadap pengelolaan sumberdaya tersebut, pemerintah dan entitas publik lainnya harus akuntabel mempertanggung jawabkan kepada pemberi kontribusi sumberdaya atau yang membutuhkan jasa dari pemerintah atau entitas publik lainnya (IFAC, 2014:13).

Akuntabilitas pengelolaan keuangan negara direpresentasikan entitas publik dalam bentuk laporan keuangan. Dari perspektif entitas (entity theory) laporan keuangan dianggap sebagai pengganti kepemilikan, karena sistem pengendalian dan pengelolaan terhadap modal terpisah dari pemilik (IASB, 2008). Dengan demikian, tujuan umum pelaporan keuangan sektor publik adalah untuk menunjukan akuntabilitas pengelolaan sumberdaya yang dipercayakan kepada manajemen entitas sektor publik dan menyediakan informasi yang berguna untuk pengambilan keputusan (Wynne, 2003:5).

Untuk memberikan kegunaan maksimal, manajemen tidak hanya dituntut untuk menghasilkan laporan keuangan, akan tetapi harus mampu menyajikan laporan keuangan yang berkualitas tinggi (Subramanyam \& Wild, 2009:67; Ferrero, 2014:50). Hasil penelitian terdahulu telah menyediakan bukti bahwa laporan keuangan berkualitas dapat memitigasi problem asimetri informasi (Healy \& Palepu, 2001:406; Verdi, 2006:29), moral hazard (Biddle et al., 2009:1; McDermott, 2011:2), sehingga meningkatkan efisiensi dan efektivitas alokasi serta utilisasi sumberdaya ekonomi (Bushman \& Smith, 2001: 2; World Bank, 2011:5; Feng Chen et al., 2010).

Seperti halnya terminologi kualitas audit, belum ada definisi kualitas pelaporan keuangan yang telah diterima secara universal. Masing-masing definisi tergantung preferensi, konteks, dan kebutuhan spesifik pengguna (Beest, et al., 2009:3). Menurut Richardson \&Tuna (2008) kualitas laporan keuangan yaitu laporan keuangan yang secara akurat menyediakan gambaran kinerja operasional dan berguna untuk perencanaan masa yang akan datang. Menurut Robinson \& Munter (2004) laporan keuangan berkualitas tinggi yaitu laporan keuangan yang secara keseluruhan, termasuk pengungkapan, menyajikan secara wajar kegiatan operasional dan posisi keuangan entitas. Gerald (2008) berpendapat bahwa laporan keuangan berkualitas tinggi yaitu laporan yang relevan, dapat dipercaya, bermakna, akurat, dan secara komprehensif menginformasikan pelayanan (stewardship) manajemen, baik dalam angka ataupun data operasional lainnya. Sedangkan Scott (2009) mendefinisikan kualitas laporan keuangan sebagai laporan keuangan yang sangat informatif berdasarkan sistem informasi yang mendasarinya atau transparan, dan akurat atau berkualitas tinggi karena memberikan banyak informasi kepada pengguna laporan keuangan. Namun, umumnya pemakai laporan keuangan menilai laporan auditor sebagai indikator keandalan laporan keuangan, karena informasi yang telah diaudit oleh auditor independen diasumsikan menjadi lengkap, akurat, tidak bias (Arens et al., 2012). Hal ini sejalan dengan Dewan standar IASB dan FASB sepakat bahwa informasi yang dapat diverifikasi (verifiability) secara independen pada umumnya lebih berguna (IASB, 2008). Akhir-akhir ini popular "a three-legged reporting model" yang memuat kinerja ekonomi, lingkungan, dan sosial karena lebih memberikan kegunaan komprehensif bagi pemangku kepentingan (Baron, 2014;KPMG, 2013). Namun sebagian besar informasi bersifat subyektif dan pengungkapan informasi tidak berkaitan langsung dengan laporan keuangan (IAASB, 2012). 
Penyebab belum tersedianya alat pengukuran kualitas pelaporan keuangan yang disepakati secara universal yaitu persepsi dan preferensi kegunaan laporan keuangan sifatnya spesifik tergantung kebutuhan pemakai informasi, (Dechow and Dichev, 2002; Schipper and Vincent, 2003; Botosan, 2004; Daske and Gebhardt, 2006 dalam Beest et al., 2009). Sebagai akibatnya, pengukuran kualitas menjadi problematik (Botosan, 2004 dalam Beest et al., 2009). Namun secara konseptual menurut IAASB (2011), perspektif output audit berpengaruh penting terhadap kualitas audit karena seringkali laporan keuangan hasil audit dipertimbangkan stakeholder dalam penilaian kualitas audit. Laporan auditor berpengaruh positif terhadap kualitas audit apabila hasil (outcome) audit yang disampaikan jelas disertai komunikasi permasalahan yang ditemukan dengan pihak yang bertanggungjawab terhadap tata kelola (those charged with governance), seperti aspek kualitatif praktik pelaporan keuangan entitas dan kelemahan pengendalian intern dapat berpengaruh positif terhadap kualitas audit. (IAASB, 2011).

Berkaitan dengan pengukuran kualitas pelaporan keuangan, Feng Chen et al., (2010:15) mengemukakan "There is no one universally agreed upon measure of FRQ". Dalam literatur, sebagian besar mengukur kualitas laporan keuangan dengan kebijakan akrual (discretionary accruals) (Francis et al., 2006:41; Beest et al., 2009), value relevance yang menghubungkan antara reaksi harga pasar saham dengan angka-angka akuntansi. Disamping itu, melalui pengukuran elemen-elemen tertentu laporan tahunan seperti laporan auditor (Beest, et al., 2009: 7-8).

Pada penelitian ini, kualitas pelaporan keuangan diukur dengan laporan keuangan yang mendapat opini auditor. Opini auditor dapat berupa opini unmodified (WTP) atau modified. Opini yang dimodifikasi yaitu opini qualified atau wajar dengan pengecualian (WDP), antara lain adanya ketidaksepakatan sesuai kriteria dari auditor atau auditor tidak dapat memperoleh bukti audit yang cukup dan akurat mengenai akun-akun tertentu yang mungkin dapat berdampak material tetapi tidak pervasif; Opini tidak wajar (adverse) yaitu ketika auditor setelah memperoleh bukti audit yang cukup dan akurat, akan tetapi karena adanya pembatasan ruang lingkup audit atau adanya ketidakpastian yang keduanya material atau pervasif; Opini tidak memberikan pendapat (disclaimed) dimana auditor tidak dapat memperoleh bukti audit yang cukup dan tepat karena ketidakpastian atau pembatasan ruang lingkup audit yang keduanya material dan pervasif (ISSAI 100:16).

Jenis opini audit yang diterapkan BPK, sesuai Keputusan BPK RI Nomor 4/K/1XIII.2/7/2014 tentang Petunjuk Pelaksanaan Pemeriksaan Keuangan, meliputi empat jenis opini, yakni opini audit wajar tanpa pengecualian (WTP) atau unqualified opinion, karena laporan keuangan menyajikan secara wajar dalam semua hal yang material sesuai dengan standar akuntansi pemerintahan (SAP); Wajar dengan pengecualian (WDP) atau qualified opinion, yaitu ketika laporan keuangan menyajikan secara wajar dalam semua hal yang material sesuai dengan SAP, kecuali untuk dampak hal-hal yang berhubungan dengan yang dikecualikan; Tidak wajar (TW) atau adverse opinion, karena laporan keuangan tidak menyajikan secara wajar dalam semua hal yang material sesuai dengan SAP; dan Pernyataan menolak memberikan opini atau tidak memberikan pendapat (TMP) atau disclaimer opinion. Dalam laporan audit, alasan pemberian opini termasuk penyebab menolak atau tidak dapat menyatakan pendapat diungkapkan dalam laporan hasil pemeriksaan (BPK, 2014: 49-50).

Namun diantara semua opini auditor, opini wajar tanpa pengecualian (unmodified auditor's report) meningkatkan kepercayaan parlemen, dewan legislatif dan pemangku kepentingan lainnya terhadap entitas (ANAO, 2015). Bagi pengguna laporan keuangan, 
laporan keuangan dengan opini audit unmodified atau tanpa pengecualian merupakan sinyal penting tentang keandalan dari informasi keuangan (IAASB, 2014:15).

Berdasarkan uraian definisi dan hasil penelitian terdahulu, pada penelitian ini, pengukuran kualitas laporan keuangan menggunakan proksi opini auditor.

Kualitas Audit dan Kualitas Laporan Keuangan. Sesuai definisi dan hasil analisis DeAngelo (1981:186) bahwa output audit dapat dianggap sebagai karakteristik verifikasi auditor independen sedangkan opini yang diberikan berkaitan dengan dimensi kualitas keuangan manajemen. Demikian juga pendapat Defond \& Zhang (2014:276) bahwa "... audit quality is a component of financial reporting quality", maka dapat dikatakan bahwa kualitas audit berpengaruh terhadap kualitas laporan keuangan.

Menurut IAASB (2011), laporan auditor berpengaruh positif terhadap kualitas audit apabila hasil (outcome) audit yang disampaikan jelas disertai komunikasi permasalahan yang ditemukan dengan pihak yang bertanggungjawab terhadap tata kelola (those charged with governance), seperti aspek kualitatif praktik pelaporan keuangan entitas dan kelemahan pengendalian intern dapat berpengaruh positif terhadap kualitas audit.

Mengacu pada definisi DeAngelo (1981:186) bahwa kualitas audit adalah probabilitas auditor menemukan penyimpangan dan kemampuan melaporkan penyimpangan akuntansi. Namun jika tidak ditindaklanjuti oleh auditi maka jumlah temuan temuan audit yang sangat banyak tidak memenuhi kriteria karena "nilai" dari suatu audit sebagaimana dinyatakan IFAC (2013:62) "Actions taken by the entity in response to recommendations are often recorded and seen as an expression of the value from the audits". Menurut Ince (2016:120) bagian dari filosofi audit yang paling kritikal untuk meningkatkan kesadaran akuntabilitas auditi hanya melalui mekanisme tindak lanjut yang efektif. Demikian juga hasil penelitian Setyaningrum et al., (2013:89) menemukan bahwa "... high quality auditor is able to produce appropriate recommendations that can be easily followed up by the auditee"

Audit laporan keuangan sektor publik selain melakukan penilaian kesesuaian penyajian laporan keuangan dengan standar akuntansi pemerintah, juga melakukan pengujian atas efektivitas sistem pengendalian intern dan kepatuhan terhadap peraturan dan perundang-undangan (Kearney et al., 2013:6; IAASB, 2013:62, Petunjuk Pelaksanaan Pemeriksaan Keuangan BPK RI Nomor 4/K/1-XIII.2/7/2014).

Defisiensi pengendalian intern yang signifikan (material weakness) diantaranya disebabkan kegagalan manajemen tidak melakukan tindakan perbaikan secara tepat (IAPI, 2013: SA265.7-8). Aikins (2012:198-217) menemukan bahwa pemeliharaan dokumen yang tidak cermat atas isu kelemahan pengendalian tidak memperkuat akuntabilitas entitas publik. He (2009) menemukan bahwa persepsi investor meningkat setelah adanya perbaikan pengendalian internal. Doyle et al. (2007:1141) membuktikan bahwa pengendalian internal yang lemah berhubungan dengan kualitas laporan keuangan. IAASB (2011) menyatakan bahwa aspek kelemahan pengendalian intern dapat berpengaruh terhadap kualitas audit.

Pengendalian internal adalah alat mencegah, mendeteksi, mengoreksi kesalahan (Garrett, et al., 2012:17) dan kecurangan pelaporan keuangan (Amernic, 2010:11), sehingga laporan keuangan disajikan secara wajar (Ratcliffe \& Landes, 2009). AshbaughSkaife, et al. 2008 menemukan hubungan yang signifikan dan positif antara perbaikan pengendalian internal yang lemah dengan kualitas laporan keuangan (dalam Hunton, et al., 2010:3). Berdasarkan berbagai definisi dan hasil penelitian terdahulu, dapat dikatakan 
bahwa tindak lanjut atas temuan tentang kelemahan pengendalian intern akan berpengaruh terhadap kualitas laporan keuangan.

Dalam kaitannya dengan ketidakpatuhan terhadap peraturan dan perundangundangan, antara lain ketidakpatuhan manajemen terhadap peraturan perundang-undangan karena ketidakmampuan manajemen melakukan pengawasan proses penyusunan laporan keuangan (IAPI, 2013: SA265.12). Pada umumnya, kecurangan pelaporan keuangan disebabkan manajemen mengabaikan (override) sistem pengendalian intern (IAPI, 2013: SA550.19-20; Hermanson, et al., 2012:A48; COSO,2011:14; Arens, et al., 2014:309). Hasil penelitian terdahulu Zhang et al. (2016) menemukan bahwa perusahaan yang tidak taat terhadap hukum mengakibatkan permasalahan pelaporan keuangannya lebih tinggi. Nagy (2010) menemukan hubungan negatif antara kepatuhan dengan kesalahan penyajian laporan keuangan. Kedia et al., (2016:1) menemukan bahwa dalam perusahaan yang memiliki kultur tidak patuh cenderung salah penyajian laporan keuangan.

Berdasarkan beberapa definisi dan uraian sebagaimana telah dikemukakan, dapat dikatakan bahwa tindak lanjut perbaikan atas ketidakpatuhan peraturan dan perundangundangan merupakan indikator kualitas audit (misalnya Ince, 2016:120; IFAC, 2013:62) yang pada akhir berdampak positif pada kualitas laporan keuangan (misalnya, Deloitte, 2015:54-55; Defond, \& Zhang, 2014:275; ISSAI 100). Dengan kata lain, tindak lanjut perbaikan atas temuan dan permasalahan ketidakpatuhan terhadap peraturan perundangundangan berpengaruh terhadap kualitas laporan keuangan.

Dengan demikian hipotesis pada penelitian ini yaitu:

$\mathrm{H}_{1}$ : Tindak lanjut perbaikan atas kelemahan sistem akuntansi dan pelaporan berpengaruh terhadap kualitas laporan keuangan

$\mathrm{H}_{2}$ : Tindak lanjut perbaikan atas kelemahan pelaksanaan anggaran berpengaruh terhadap kualitas laporan keuangan

$\mathrm{H}_{3}$ : Tindak lanjut perbaikan atas kelemahan struktur pengendalian intern berpengaruh terhadap kualitas laporan keuangan

$\mathrm{H}_{4}$ : Tindak lanjut perbaikan atas ketidakpatuhan terhadap peraturan dan perundangundangan berpengaruh terhadap kualitas laporan keuangan

\section{METODE}

Objek penelitian ini adalah kualitas audit dan kualitas laporan keuangan. Objek penelitian adalah aktivitas yang bertentangan dengan aktivitas kognitif yang diekspresikan dengan keberadaan fenomena, sehingga menjadi dasar tujuan penelitian (Novikov \& Novikov, 2013:66-67). Untuk mencapai tujuan penelitian, diperlukan metode penelitian (Kothari, 2004:36) yang digunakan secara ilmiah yaitu rasional, empiris, dan sistematis meliputi pengukuran, pengumpulan data, dan penggunaan teknik statistik untuk analisis dan evaluasi hubungan antar variabel (Kothari, 2004:7; Sugiyono, 2012:2). Metode penelitian diawali dengan operasionalisasi variabel (Kothari, 2004:8; Sekaran \& Bougie, 2013:95) untuk mengurangi tingkat keabstrakan suatu konstruk agar dapat diobservasi, dengan menetapkan indikator disertai skala pengukuran (Sekaran \& Bougie, 2013:200).

Operasionalisasi variabel kualitas audit menggunakan proksi tingkat penyelesaian atau tingkat tindak lanjut perbaikan atas temuan permasalahan kelemahan sistem pengendalian intern, meliputi pengendalian intern akuntansi dan pelaporan, pelaksanaan anggaran, dan struktur pengendalian, serta tingkat penyelesaian atas temuan permasalahan ketidakpatuhan terhadap peraturan dan perundang-undangan. Pengendalian intern adalah 
berfungsinya alat identifikasi, pencegahan, dan koreksi secara real-time sehingga laporan keuangan dapat diandalkan untuk pengambilan keputusan (COSO, 2009:1-2), sedangkan kepatuhan (compliance) adalah kepatuhan berkaitan dengan pengelolaan sektor publik terhadap peraturan dan perundang-undangan yang berlaku, antara alain proses dan prosedur penggunaan uang negara (ISSAI 100:8). Dengan adanya tindakan perbaikan atas temuan audit kelemahan sistem pengendalian intern dan ketidakpatuhan terhadap perundang-undangan, kualitas laporan keuangan meningkat.

Kualitas audit diukur dengan persentase tingkat penyelesaian temuan permasalahan dengan skala 5 jika tingkat penyelesaian temuan permasalahan $81-100 \%$, skala $2=61$ $80 \%$, skala $3=41-60 \%$, skala $2=21-40 \%$, dan skala $1=0-20 \%$. Operasionalisasi variabel kualitas laporan keuangan menggunakan proksi opini audit. Semakin kecil kesalahan penyajian atau ketidaksesuaian dengan SAP, laporan keuangan semakin berkualitas, karena opini audit unmodified (WTP) lebih mendapatkan kepercayaan dan lebih andal untuk pengambilan keputusan oleh pengguna laporan keuangan (ANAO, 2015; IAASB, 2014; Arens et al., 2012). Skala pengukuran sesuai kualitas onini auditor terhadap laporan keuangan, untuk $\mathrm{WTP}=5$, WTD DPP=4, WDP=3, TW=2, dan TMP=1.

Penelitian menggunakan data sekunder karena lebih efisien daripada perolehan informasi melalui survei lapang (Kotari, 2004; Hair, et al.,2014). Data yang digunakan yaitu ikhtisar temuan dan tindak lanjut perbaikan atas LKPD tahun 2011-2015 antara lain dari IHPS dan Laporan Akuntabilitas Kinerja. Karena data sekunder tersebut diterbitkan secara formal diharapkan data memenuhi persyaratan "reliable, suitable and adequate" (Kotari, 2004). Populasi merupakan wilayah generalisasi yang memiliki kualitas dengan karakteristik tertentu untuk dipelajari dan ditarik kesimpulan (Sugiyono, 2012:80). Pada penelitian ini populasi adalah LPKD yang merepresentasikan akuntabilitas pengelolaan sumberdaya oleh pemerintah daerah, provinsi, kota, dan kabupaten, yang secara teori berpotensi menimbulkan agency problem, sehingga memerlukan tata kelola yang baik, terutama dalam pengawasan maupun sistem pengendalian internal dan kepatuhan. Melalui sistem tata kelola yang baik stakeholders mendapatkan informasi keuangan yang berkualitas sebagai dasar pengambilan keputusan (Jensen \& Meckling, 1976; IFC, 2014). Target populasi ditetapkan berdasarkan geografis dan waktu (Sekaran \& Bougie, 2013:245). Unit analisis pada penelitian ini adalah Pemda di Indonesia, dengan sampel pada Pemda Sumatera dan Jawa sebagai unit analisis agregasi dari data yang dikumpulkan (Sekaran \& Bougie, 2013:103) sebagai dasar untuk dilakukan pengujian dan analisis statistik dalam rangka generalisasi (Ceci, 2005:31). Metode analisis yang digunakan adalah analisis regresi (least square method).

Tabel 1. Operasionalisasi Variabel

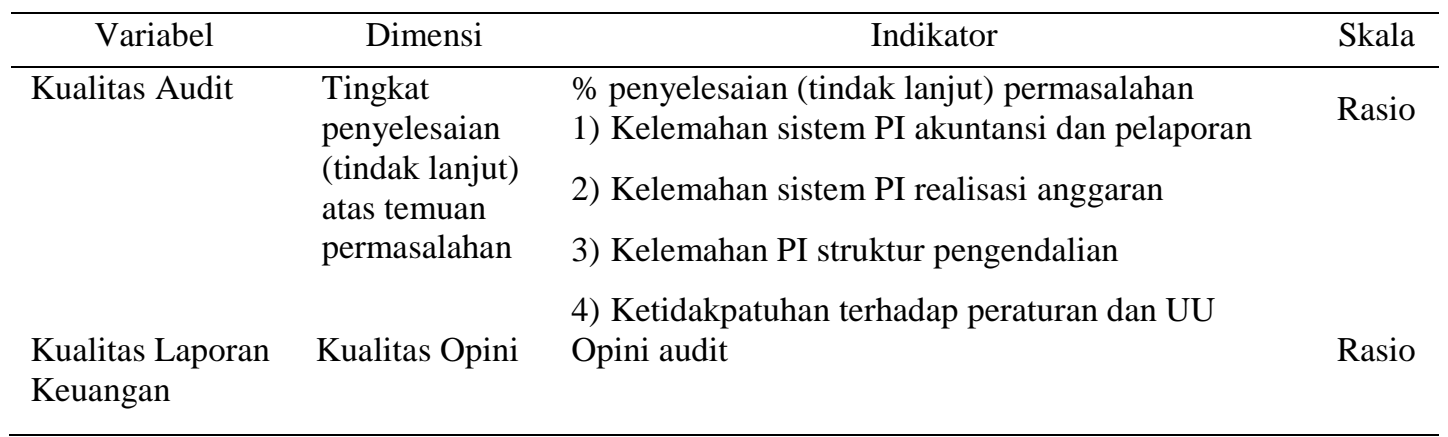

Keterangan: $\mathrm{PI}=$ Pengendalian intern; UU = perundang-undangan 


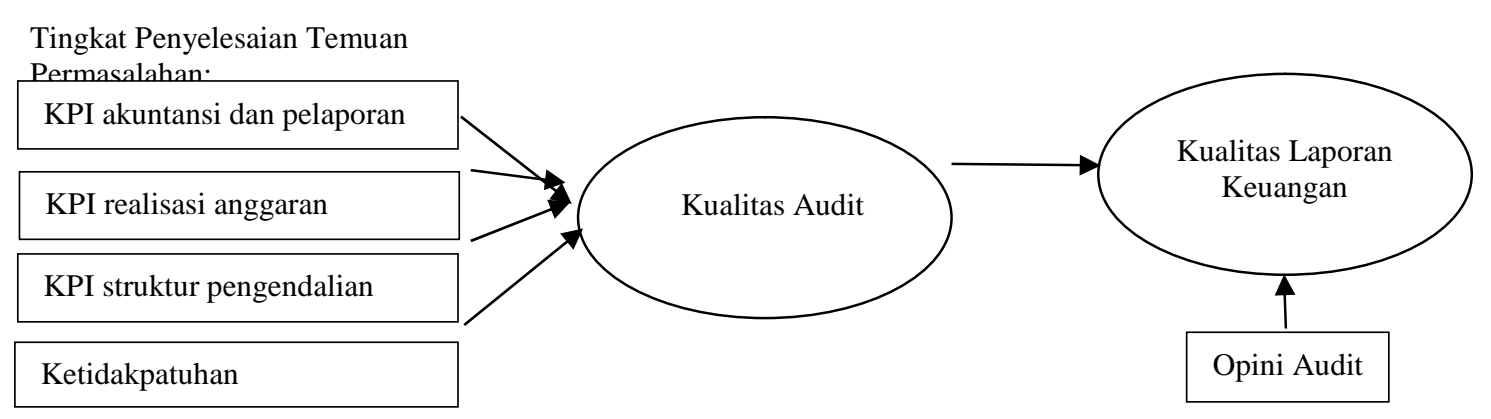

Gambar 3. Kerangka Pemikiran Konseptual

Keterangan: KPI = kelemahan pengendalian intern

\section{HASIL DAN PEMBAHASAN}

Analisis Deskriptif. Analisis deskriptif memberikan gambaran umum mengenai data dan penyebarannya dalam penelitian ini, berupa nilai rata-rata, nilai maksimum, nilai minimum dan standar deviasi.

Tabel 2. Statistik Deskriptif

\begin{tabular}{cccccc}
\hline Variabel & $\mathrm{N}$ & Mean & Max & Min & Std. Deviasi \\
\hline $\mathrm{X}_{1}$ & 279 & 3,65 & 5,10 & 1,81 & 0,68 \\
$\mathrm{X}_{2}$ & 279 & 3,69 & 5,16 & 2,13 & 0,65 \\
$\mathrm{X}_{3}$ & 279 & 3,76 & 5,23 & 1,81 & 0,65 \\
$\mathrm{X}_{4}$ & 279 & 3,53 & 5,02 & 1,00 & 0,67 \\
\hline
\end{tabular}

$\mathrm{X}_{1}$ yaitu tingkat penyelesaian atau tindak lanjut perbaikan atas temuan permasalahan kelemahan sistem pengendalian intern akuntansi dan pelaporan, $\mathrm{X}_{2}$ tingkat penyelesaian atau tindak lanjut perbaikan atas temuan permasalahan kelemahan sistem pengendalian pelaksanaan anggaran, $X_{3}$ tingkat penyelesaian atau tindak lanjut perbaikan atas temuan permasalahan kelemahan struktur pengendalian, $\mathrm{X}_{4}$ tingkat penyelesaian atau tindak lanjut perbaikan atas temuan permasalahan ketidakpatuhan terhadap peraturan dan perundangundangan.

Berdasarkan tabel deskriptif di atas, nilai rata-rata variabel relatif sama dengan nilai terendah $\mathrm{X}_{4}$ sebesar 3,53 dan tertinggi $\mathrm{X}_{3}$ terbesar dengan nilai rata-rata 3,76. Standar deviasi masing-masing variabel tidak jauh berbeda menunjukkan data menyebar di sekitar nilai rata-rata dengan keragaman yang relatif sama.

Berdasarkan Tabel 2, dalam tahun 2011-2015 rata-rata kualitas LKDP terbesar yaitu WDP 56,06\%, terendah TW 0,50\%. Tetapi perubahan kualitas LKPD tahun 2015 dibandingkan tahun 2011 menunjukkan perbaikan signifikan pada WTP yaitu sebesar 46.59\%. Jumlah tersebut merupakan peningkatan LKPD yang pada tahun-tahun sebelumnya mendapat opini WTP DPP sehingga berkurang sebanyak 7,89\% dan WDP sebesar $38,35 \%$. 
Djanegara: Pengaruh Kualitas Audit Terhadap Kualitas Laporan Keuangan Pemerintah...

Tabel 2. Statistik Deskriptif Variabel Kualitas Pelaporan Keuangan (dalam \%)

\begin{tabular}{lrrrrrrr}
\hline $\begin{array}{c}\text { Kualitas } \\
\text { Opini }\end{array}$ & 2011 & 2012 & 2013 & 2014 & 2015 & $\begin{array}{l}\text { Kualitas } \\
\text { rata-rata }\end{array}$ & $\begin{array}{c}\text { Peningkatan } \\
\text { kualitas }\end{array}$ \\
\hline WTP & 11.11 & 21.86 & 16.13 & 29.39 & 57.71 & 27.24 & 46,59 \\
WTP DPP & 9.32 & 8.96 & 18.28 & 22.58 & 1.43 & 12.11 & $(7,89)$ \\
WDP & 74.19 & 64.52 & 60.93 & 44.8 & 35.84 & 56.06 & $(38,35)$ \\
TW & 0.36 & 0.72 & 0.72 & 0.72 & 0.00 & 0.50 & $(0,36)$ \\
TMP & 5.02 & 3.94 & 3.94 & 2.51 & 2.15 & 3.51 & $(2,87)$ \\
\hline
\end{tabular}

Analisis uji verifikatif. Hasil analisis regresi menunjukkan bahwa goodness of fit model cukup baik dengan nilai $F$ sebesar151,15 (nilai significance $F=0,0000$ ). Model regresi signifikan pada tingkat alpha 5\%. Nilai koefisien determinasi $R$-square model menunjukkan sebesar 0,6881yang berarti 68,81\% keragaman variabel Y kualitas pelaporan keuangan dapat dijelaskan oleh keempat variabel independen $X_{1}$ tingkat penyelesaian atau tindak lanjut perbaikan atas kelemahan sistem pengendalian intern akuntansi dan pelaporan, $X_{2}$ tingkat penyelesaian atau tindak lanjut perbaikan atas kelemahan sistem pengendalian intern pelaksanaan anggaran, $\mathrm{X}_{3}$ tingkat penyelesaian atau tindak lanjut perbaikan atas kelemahan struktur pengendalian, dan $\mathrm{X}_{4}$ tingkat penyelesaian atau tindak lanjut perbaikan atas kelemahan ketidakpatuhan terhadap peraturan dan perundang-undangan. Berdasarkan hasil uji $\mathrm{F}$ dan nilai koefisien determinasi tersebut menunjukkan bahwa model regresi dapat digunakan untuk penelitian ini.

Model regresi yang digunakan:

$Y=(0,0857)+0,4035 X_{1}+0,1998 X_{2}+0,1505 X_{3}+0,1470 X_{4}$

Keterangan:

$\mathrm{Y}=$ Kualitas Laporan Keuangan

$\mathrm{X}_{1}=$ Tindak lanjut perbaikan atas kelemahan Sistem PI akuntansi dan pelaporan

$\mathrm{X}_{2}=$ Tindak lanjut perbaikan atas kelemahan Sistem PI pelaksanaan anggaran

$\mathrm{X}_{3}=$ Tindak lanjut perbaikan atas kelemahan Sistem PI struktur pengendalian

$\mathrm{X}_{4}=$ Tindak lanjut perbaikan atas kelemahan ketidakpatuhan terhadap peraturan dan per UU-an

Tabel 3. Hasil Analisis Regresi

Faktor-Faktor yang Mempengaruhi Kualitas Pelaporan Keuangan

\begin{tabular}{lcccc}
\hline & Coefficients & Standard Error & $t$-stat & P-value \\
\hline Intercept & $(0,0857)$ & 0,1460 & $(0,6094)$ & 0,5427 \\
$\mathrm{X}_{1}$ & 0,4035 & 0,0569 & 7,0966 & 0,0000 \\
$\mathrm{X}_{2}$ & 0,1998 & 0,0544 & 3,6694 & 0,0000 \\
$\mathrm{X}_{3}$ & 0,1505 & 0,0566 & 2,7077 & 0,0072 \\
$\mathrm{X}_{4}$ & 0,1470 & 0,0574 & 2,5631 & 0,0109 \\
\hline
\end{tabular}

Berdasarkan Tabel di atas hipotesis $\left(\mathrm{H}_{1}\right)$ bahwa tindak lanjut perbaikan atas kelemahan sistem akuntansi dan pelaporan berpengaruh terhadap kualitas laporan keuangan didukung secara empiris. Dari hasil analisis, variabel $\mathrm{X}_{1}$ memiliki $p$-value sebesar $0,0000(<\alpha=0,05)$ yang berarti $X_{1}$ signifikan pada tingkat alpha $5 \%$. Dengan kata 
lain $\mathrm{H}_{1}$ diterima. Koefisien $\mathrm{X}_{1}$ nilainya positif yang berarti semakin baik tindak lanjut perbaikan atas kelemahan sistem akuntansi dan pelaporan maka kualitas pelaporan keuangan juga akan meningkat.

Hipotesis kedua yaitu tindak lanjut perbaikan atas kelemahan pelaksanaan anggaran berpengaruh terhadap kualitas laporan keuangan. Hasil pengujian menunjukkan bahwa tindak lanjut perbaikan atas kelemahan pelaksanaan anggaran memiliki nilai $t$-stat sebesar 7,0966 dengan $p$-value $0,0000(<\alpha=0,05)$ yang berarti variabel $\mathrm{X}_{2}$ ini berpengaruh signifikan terhadap kualitas pelaporan keuangan pada tingkat alpha 5\%. Koefisien $X_{2}$ bernilai positif menunjukkan semakin baik tindak lanjut perbaikan atas kelemahan pelaksanaan anggaran maka akan meningkatkan kualitas pelaporan keuangan.

Hipotesis ketiga yaitu tindak lanjut perbaikan atas kelemahan struktur pengendalian intern berpengaruh terhadap kualitas laporan keuangan. Hasil pengujian menunjukkan variabel $\mathrm{X}_{3}$ ini mempunyai nilai $t$-stat 0,0556 dengan $p$-value sebesar $0,0072(<\alpha=0,05)$, maka variabel $\mathrm{X}_{3}$ berpengaruh secara signifikan terhadap kualitas pelaporan keuangan. Hipotesis ketiga diterima pada tingkat alpha 5\%. Nilai koefisien $\mathrm{X}_{3}$ adalah positif maka tindak lanjut perbaikan atas kelemahan struktur pengendalian intern akan meningkatkan kualitas laporan keuangan.

Hipotesis keempat yaitu tindak lanjut perbaikan atas ketidakpatuhan terhadap peraturan dan perundang-undangan berpengaruh terhadap kualitas laporan keuangan. Hasil pengujian menunjukkan variabel $\mathrm{X}_{4}$ berpengaruh secara signifikan terhadap kualitas pelaporan keuangan dengan nilai $t$-stat 2,5631 dan $p$-value $0,0109(<\alpha=0,05)$. Hipotesis keempat diterima pada tingkat alpha $5 \%$. Koefisien $\mathrm{X}_{4}$ positif yang menunjukkan semakin baik tindak lanjut perbaikan atas ketidakpatuhan terhadap peraturan dan perundangundangan akan meningkatkan kualitas pelaporan keuangan.

Dari keempat variabel ini yang paling besar pengaruhnya terhadap kualitas pelaporan keuangan adalah $\mathrm{X}_{1}$ yaitu tindak lanjut perbaikan atas kelemahan sistem akuntansi dan pelaporan (nilai koefisiennya 0,4035). Sedangkan variabel $\mathrm{X}_{4}$ paling kecil pengaruhnya terhadap kualitas pelaporan keuangan (nilai koefisiennya 0,1470 ).

Hasil penelitian dapat dikatakan sejalan dengan penelitian terdahulu Setyaningrum et al. (2013:89), bahwa kualitas audit berpengaruh positif terhadap kualitas laporan keuangan. Temuan ini mengindikasikan bahwa semakin tinggi tingkat penyelesaian atau tindak lanjut perbaikan atas kelemahan pengendalian intern kualitas LKPD semakin meningkat. Di antara ke empat variabel independen, pengaruh terbesar terhadap peningkatan kualitas LKPD ditunjukkan oleh variabel $\mathrm{X}_{1}$ tingkat penyelesaian atau tindak lanjut perbaikan atas kelemahan pengendalian akuntansi dan pelaporan. Variabel lainnya menunjukkan koefisien yang relatif sama.

\section{PENUTUP}

Kesimpulan. Kualitas audit dan kualitas laporan keuangan merupakan supply chain dalam meningkatkan akuntabilitas dan pertanggunjawaban pengelolaan keuangan negara. Berdasarkan hasil uji verifikatif dapat disimpulkan tingkat penyelesaian atau tindak lanjut perbaikan atas temuan permasalahan dan rekomendasi hasil audit BPK berpengaruh signifikan dan positif terhadap peningkatan kualitas LKPD.

Di antara temuan hasil audit BPK, tingkat penyelesaian atau tindak lanjut perbaikan atas temuan kelemahan pengendalian intern akuntansi dan pelaporan memiliki pengaruh paling besar terhadap perbaikan opini LKPD. Sedangkan tindak lanjut perbaikan atas 
temuan lainnya, yaitu tindak lanjut perbaikan atas kelemahan pengendalian realisasi anggaran, dan struktur pengendalian, serta ketidakpatuhan terhadap peraturan dan perundang-undangan meskipun berpengaruh positif menunjukan besaran pengaruh yang relatif sama terhadap perbaikan kualitas opini LKPD.

Saran. Berdasarkan hasil penelitian, untuk meningkatkan kualitas LKPD diperlukan pemantauan tindak lanjut perbaikan atas temuan permasalahan dan rekomendasi atas kelemahan pengendalian intern dan ketidakpatuhan terhadap peraturan perundangudangan. Namun demikian, prioritas utama yaitu pemantauan tindak lanjut perbaikan atas kelemahan pengendalian akuntansi dan pelaporan.

Bagi Pemda, pengendalian intern akuntansi dan pelaporan meliputi ketersediaan sarana dan prasarana sistem informasi akuntansi dan sumber daya manusia yang memadai. Sedangkan bagi BPK, frekuensi pemantauan atas tindak lanjut perbaikan secara periodik perlu ditingkatkan dengan menggunakan fasilitas sistem aplikasi SIPTL (sistem informasi pemantauan tindak lanjut) yang telah dimiliki.

Oleh karena penelitian tentang tindak lanjut perbaikan atas temuan audit masih relatif sedikit, hasil penelitian ini dapat dilanjutkan sebagai bahan penelitian berikutnya dan sekaligus sebagai dasar untuk lebih memperkaya pelaksanaan perbaikan pemantauan tindak lanjut hasil temuan audit dan perbaikan kualitas laporan keuangan.

\section{DAFTAR RUJUKAN}

Adam, Michael B, (1994) "Agency Theory and the Internal Audit", Managerial Auditing Journal, 9 (8), 8-12, MCB University Press.

Aikins, Stephen Kwamena. (2012) "Determinants of Auditee Adoption of Audit Recommendations: Local Government Auditors' Perspectives”. Journal of Public Budgeting, Accounting \& Financial management, 24 (2),195-220.

Amernic, Joel, Russell Craig, \& Dennis Tourish. (2010) Measuring and Assessing Tone at the Top Using Annual Report CEO Letters. Edinburgh: The Institute of Chartered Accountants of Scotland, T. J. International Ltd.

ANAO (Australian National Audit Office). (2015) Public Sector Financial Statements High-Quality Reporting Through Good Governance and Process. Better Practice Guide: March 2015. Commonwealth of Australia 2015. Australian National Audit Office.

Arens, Alvin A., Randal J. Elder, \& Mark S. Beasley. (2012) Auditing and Assurance Services-An Integrated Approach. Fifteenth Edition. England: Pearson Education Inc.

Arens, Alvin A., Randal J. Elder, \& Mark S. Beasley. (2014) Auditing and Assurance Services-An Integrated Approach. Fifteenth Edition. England: Pearson Education Inc.

Baron, R. (2014) The Evolution of Corporate Reporting for Integrated Performance.Background paper for the 30th Round Table on Sustainable Development 25 June 2014. Paris : OECD Headquarters.

Beest, F. van, B. Braam,\& S. Boelens. (2009) Quality of Financial Reporting: Measuring Qualitative Characteristics. NiCE Working Paper. Nedherland: Radboud University Nijmegen. 
Benedek, Mária, Klára Tubak Szenténé, dan Dániel Béres. (2014) Internal Controls in Local Governments. Focus - Transforming Local Governments. Public Finance Quarterly 2014/3.

Biddle, Gary C., Gilles Hilary, \& Rodrigo S. Verdi. (2009) "How Does Financial Reporting Quality Relate to Investment Efficiency?" Journal of Accounting and Economics. 48(2-3), 111-236.

Bing, Jueming (Jimmy), Chu Xin Huang, Anqi (Linda) Li. Xinyi (Lydia) Zhu. (2014) "Audit Quality Research Report. A report prepared by the 2013-14 Summer Interns in the Research". School of Accounting and Business Information Systems. 21 January 2014

Botosan, Christine A, (1997) Disclosure Level and the Cost of Equity Capital, The Accounting review, 72 (3) Juli, 323-349

Brennan, Niamh M., (2007) "Introduction. Corporate governance and financial reporting", SAGE Library in Accounting and Finance, Juli 2007

Brooks, Richard C. \& David B. Pariser. (1995) "Audit Recommendation Follow-Up Systems: A Survey of the States”. Public Budgeting \& Finance. 15 (1). March 7283

Bushman, R.M., \& A.J. Smith. (2001) "Financial Accounting Information and Corporate Governance". Journal of Accounting and Economics. 32, 237-333.

Ceci, Michelangelo. (2005) "Naive Bayesian Learning from Structural Data". Dissertation. Italy: the Graduate Division of the University of Bari.

Chau, S L, (2011) "An Anatomy of Corporate Governance", The IUP Journal of Corporate Governance, X (1).

COSO. (2009) Internal Control - Integrated Framework. Guidance on Monitoring Internal Control Systems. Introduction. Jersey City: Committee of Sponsoring Organizations of the Treadway Commission.

COSO. (2011) Internal Control Integrated Framework. Jersey City: Committee of Sponsoring Organizations of the Treadway Commission.

COSO. (2013) Internal Control-Integrated Framework,Executive Summary. Jersey City:Committee of Sponsoring Organizations of the Treadway Commission.

Daniri, Mas Achmad dan Angela Indirawati Simatupang, Rekayasa Pelaporan Keuangan: Isu Akuntansi atau Governance?

DeAngelo, Linda Elizabeth. (1981) "Auditor Size and Audit Quality". Journal of Accounting and Economics, 3, 183-199. North-Holland Publishing Company

Dechow Patricia M. \& Douglas J. Skinner. (2000) "Earnings Management: Reconciling the Views of Accounting Academics, Practitioners, and Regulators". American Accounting Association Accounting Horizons. 14(2), 235-250.

Defond, Mark and Jieying Zhang. (2014) "A Review of Archival Auditing Research". Journal of Accounting and Economics. 58, 275-326. Elsevier B.V (http://creativecommons.org/licenses/by-nc-nd/3.0/).

Deloitte, Middle East. (2015) "Accrual accounting is for the public sector too - A perspective for Arab central governments by Mohammad Jallad and Faisal Darras. Deloitte Middle East Deloitte". A Middle East Point of View. Fall 2015

Doyle, Jeffrey, Weili Ge, \& Sarah McVay. (2007) “Accruals Quality and Internal Control over Financial Reporting”. The Accounting Review. 82 (5), 1141-1170. 
Feng Chen, Ole-Kristian Hope, Qingyuan Li, \& Xin Wang. (2010) "Financial Reporting Quality and Investment Efficiency of Private Firms in Emerging Markets". The Accounting Review. 86(4), 1255-1288

Ferrero, J.M. (2014) "Consequences of Financial Reporting Quality on Corporate Performance: Evidence at the International Level". Estudios de Economía. 41(1), 49-88.

Francis, J., P. Olsson \& K. Schipper. (2006) "Earnings Quality". Foundation and Trends in Accounting. 1(4), 259-340.

Franklin, Strier, (2005) "Conflicts of Interest in Corporate Governance", The Journal of Corporate Citizenship; Autumn, 19; ProQuest Research Library pg. 79

FRC. (2006) Discussion Paper: Promoting Audit Quality. The Financial Reporting Council Limited

Garrett, Jace, Rani Hoitash \& Douglas F. Prawitt. (2012) Trust and Financial Reporting Quality. Waltham: Department of Accountancy. Bentley University.

Gerald, (2008) What high quality financial reporting and auditing mean to the investor community? Public Accountants Conference 10 July2008 http://www.sias.org, diakses 18-02-2013

Gichana, David. (2015) "Measuring the Impact of Audit Recommendations". Supreme Auditor, 8 (02), A Publication of the Office of the Auditor-General Kenya

Hair, Joseph F, G. Thomas M. Hult, Christian M. Ringle, \& Marko Sarstedt. (2014) A Primer on Partial Least Squares Structural Equation Modeling (PLS-SEM). UK: SAGE Publications, Inc.

He, Luo. (2009) "Investor Perceived Earnings Quality and Disclosure of Internal Control Weaknesses". Thesis Doctor of Philosophy in Accounting. Canada: Queen's University.

Healy, P.M. \& Palepu, K.G. (2001) "Information Asymmetry, Corporate Disclosure, and the Capital Markets: A Review of the Empirical Disclosure Literature". Journal of Accounting and Economics. 31(1-3), 405-440

Hermanson, D.R., Smith, J.L., \& Stephens, N.M. (2012) "How Effective Organizations' Internal Controls? Insights into Specific Internal Control Elements". Current Issues in Auditing. 6(1), A31-A50.

Hunton, James E., Rani Hoitash, \&Jay C. Thibodeau. (2010) "The Relationship Between Perceived Tone at the Top and Earnings Quality". Contemporary Accounting Research. 28(4), 1190-1224

IAASB. (2011). Audit Quality an IAASB Perspective, International Auditing and Assurance Standards Board (IAASB)

IAASB. (2012) Feedback Statement the Evolving Nature of Financial Reporting: Disclosure and Its Audit Implications. New York: IAASB.

IAASB. (2014) A Framework for Audit Quality at Glance. February 2014.

IAPI. (2013) Standar Audit (SA 200): Tujuan Kesluruhan Auditor Independen dan Pelaksanaan Audit Berdasarkan Standar Audit. Jakarta: Penerbit Salemba Empat

IAPI. (2013) Standar Audit (SA 265): Pengomunikasian Defisiensi dalam Pengendalian Internal kepada Pihak yang Bertanggung Jawab terhadap Tata Kelola dan Manajemen. Jakarta: Penerbit Salemba Empat

IAPI. (2013) Standar Audit (SA 550): Pihak Berelasi. Jakarta: Penerbit Salemba Empat

IASB. (2008) Exposure Draft of An Improved Conceptual Framework for Fiancial Reporting. UK: IFRS Foundation 
IFAC. (2013) A Framework for Audit Quality. This Consultation Paper, developed and approved by the International Auditing and Assurance Standards Board (IAASB). Copyright January 2013 by the International Federation of Accountants (IFAC).

IFAC. (2014) A Framework for Audit Quality. Key Elements That Create an Environment for Audit Quality. Feb 2014. International Auditing and Assurance Standards Board (IAASB). Copyright (C) February 2014 by the International Federation of Accountants (IFAC).

IFAC. (2014) The Conceptual Framework for General Purpose Financial Reporting by Public Sebtor Entities. International Public Sector Accounting Standards Board. Copyright October 2014 by the International Federation of Accountants (IFAC).

Ikhtisar Hasil Pemeriksaan Semester (IHPS) II Tahun 2016 Jakarta. 2017 Badan Pemeriksa Keuangan RI

Ikhtisar Hasil Pemeriksaan Semester (IHPS) I Tahun 2016. September 2016 Badan Pemeriksa Keuangan RI.

Ince, Murat. (2016) Follow-Up Mechanism: A Missing-Link in Audit Cycle.

ISSAI 100. Fundamental Principles of Public-Sector Auditing. Endorsement Version. The International Standards of Supreme Audit Institutions (ISSAI). INTOSAI. www.issai.org . www: http://www.intosai.org

ISSAI 3000. Standards and guidelines for performance auditing based on INTOSAI's Auditing Standards and practical experience. The International Standards of Supreme Audit Institutions, ISSAI issued by the International Organization of Supreme Audit Institutions, INTOSAI. www.issai.org

Jensen, Michael C. dan Meckling, William. (1976) "Theory of the Firm: Managerial Behavior, Agency Costs and Ownership Structure", Journal of Financial Economics, October, 3 (4), 305-360

Kearney et al. (2013) Federal Government Auditing - Laws, Regulations, Standards, Practices, \& Sarbanes-Oxley. Second Edition. Copyright (C) 2013 by John Wiley \& Sons, Inc.

Kedia, Simi, Shuqing Luo, Shivaram Rajgopal, Roy Bernard Kester, and T.W Byrnes. 2016. Culture of Weak Compliance and Financial Reporting Risk. January 2016.

Keputusan Badan pemeriksa Keuangan Republik Indonesia Nomor 4/K/1-XIII.2/7/2014 tentang Petunjuk Pelaksanaan Pemeriksaan Keuangan. Juli 2014.

Knechel, W. Robert. (2009) Audit Lessons from the Economic Crisis: Rethinking Audit Quality. Inaugural Lecture of Professor of Auditing at Maastricht University. September 2009.

Kothari, A.R. (2004) Research Methodology: Method \& Techniques. New Delhi: New Age International (P) Ltd.

KPMG. (2013) Audit Committee Institute-Global Audit Committee Survey, KPMG International Cooperative

Laporan Akuntabilitas Kinerja (LAK). 2016. BPK RI Tahun 2016

McDermott, K.E. (2011) Financial Reporting Quality and Investment in Corporate Social Responsibility. Chapel Hill: Flagler Business School. The University of North Carolina.

Messier, William F.Jr., Steven M. Glover, Douglas F. Prawitt. (2017) Auditing \& Assurance Services - A Systematic Approach. Brigham Young University Marriott School of Management School of Accountancy. Tenth Ed. McGraw-Hill Education. 
Miettinen, (2008) The Effect of Audit Quality on the Relationship Between Audit Committee Effectiveness and Financial Reporting Quality

Nagy, Albert L. (2010) Section 404 Compliance and Financial Reporting Quality. Accounting Horizons:

Novikov, Alexander M. \& Dmitry A. Novikov. (2013) Research Methodology: From Philosophy of Science to Research Design. UK: Taylor \& Francis Group, LLC.

Palmer, Philip D., (2008) Audit Quality and Financial Report Disclosure, Flinders Business School Research Paper Series 2008-1 ISSN 1441-3906

Petunjuk Pelaksaaan Pemeriksaan Keuangan BPK RI Nomor 4/K/1-XIII.2/7/2014

Ratcliffe, Thomas A.,\& Charles E. Landes. (2009) Understanding Internal Control and Internal Control Services. New York: American Institute of Certified Public Accountants, Inc.

Richardson, S., \& I. Tuna. (2008) Evaluating Financial Reporting Quality. "International Financial Statement Analysis" Selected Reading, Chapter 17, pp. 724.

Robinson, Thomas R. Munter, (2004) Financial reporting quality: red flags and accounting warning signs. Commercial Lending Review

SAO Poland. (2014) Peer Review Report on the Supreme Audit Board of the Republic of Indonesia - Badan Pemeriksa Keuangan. April 2014. Krzysztof Kwiatkowski, President of the Supreme Audit Office of Poland. Jakarta, 16 April 2014 Supreme Audit Office of Poland

Scott, William R, (2009) Financial Accounting Theory

Sekaran, Uma \& Roger Bougie. (2013) Research Methods for Business: A Skill Building Approach. Sixth Edition. US:John Wiley \& Sons Ltd

Septiana Dwiputrianti. (2011) Effectiveness of Public Sector Audit Reports in Indonesia (Preceding and Following Audit Reform). Crawford School of Economics and Government College of Asia and the Pacific Canberra, Australia. March, 2011

Setyaningrum, Dyah, Lindawati Gani, Dwi Martani, Cris Kuntadi. (2013) "The Effect of Auditor Quality on the Follow-Up of Audit Recommendation". International Research Journal of Business Studies. 6 (2) ISSN: 2089-6271

Sinason, David H. (2000) "A Study of the Effects of Accountability and Management Risk on Auditor Materiality Decision in Public Sector Audits". J. Of Public Budgeting, Accounting \& Financial Management, 12(1), 1-21 SPRING 2000

SPKN. (2017) Standar Pemeriksaan Keuangan Negara (SPKN). Peraturan BPK RI Nomor 1 Tahun 2017. Januari 2017. Badan Pemeriksa Keuangan Republik Indonesia

Subramanyam \& Wild. (2009) Subramanyam, K.R., \& Wild J.J. (2009) Financial Statement Analysis. New York: McGraw-Hill/Irwin.

Sugiyono. (2012) Metode Penelitian Kuantitatif, Kualitatif, dan R\&D. Bandung: Alfabeta

Thanh, Huyen Cao Thi \& Tina Cheung. (2010) "Accounting Quality Insight "Comply-orExplain" Internal Control Regime". Master Thesis. Sweden: Umeå School of Business.

Verdi, Rodrigo S. (2006) Financial Reporting Quality and Investment Efficiency. Philadelphia: The Wharton School University of Pennsylvania.

World Bank. (2011) Accounting and Auditing. Report on the Observance of Standards and Codes (ROSC) Indonesia 2010 (updated in April 2011). Melalui <www.bapepam.go.id> [30/04/2011]. 
Wynne, Andy. (2003) Do Private Sector Financial Statements provide a Suitable Model for Public Sector Accounts? European Group of Public Administration annual conference on "Public Law and the Modernising State" in Portugal. September.

Zhang, Xiu-Ye and Young, Steven and Choi, Sunhwa (2016) "Noncompliance, financial reporting quality and director turnover". Thesis, Lancaster 